\title{
Optimizing revenue at a cosmetic surgery centre
}

\author{
Joanna M Funk BS ${ }^{1}$, Charles N Verheyden MD PHD², ${ }^{2,3}$ Raman C Mahabir MSc MD FRCSC ${ }^{2,3}$
}

JM Funk, CN Verheyden, RC Mahabir. Optimizing revenue at a cosmetic surgery centre. Can J Plast Surg 2011;19(3):85-87.

BACKGROUND: The demand for cosmetic surgery and services has diminished with recent fluctuations in the economy. To stay ahead, surgeons must appreciate and attend to the fiscal challenges of private practice. A key component of practice economics is knowledge of the common methods of payment.

OBJECTIVE: To review methods of payment in a five-surgeon group practice in central Texas, USA.

METHODS: A retrospective chart review of the financial records of a cosmetic surgery centre in Texas was conducted. Data were collected for the five-year period from 2003 to 2008, and included the method of payment, the item purchased (product, service or surgery) and the dollar amount. RESULTS: More than 11,000 transactions were reviewed. The most common method of payment used for products and services was credit card, followed by check and cash. For procedures, the most common form of payment was personal check, followed by credit card and financing. Of the credit card purchases for both products and procedures, an overwhelming majority of patients (more than $75 \%$ ) used either Visa (Visa Inc, USA) or MasterCard (MasterCard Worldwide, USA). If the amount of the individual transaction surpassed US $\$ 1,000$, the most common method of payment transitioned from credit card to personal check.

CONCLUSIONS: In an effort to maximize revenue, surgeons should consider limiting the credit cards accepted by the practice and encourage payment through personal check.

Key Words: Cosmetic surgery; Methods of payment; Revenue

\section{L'optimisation des revenus à un centre de chirurgie esthétique}

HISTORIQUE : La demande de chirurgies et services esthétiques a diminué en raison des récentes fluctuations de l'économie. Pour demeurer rentables, les chirurgiens doivent comprendre les défis fiscaux de la pratique privée et en tenir compte. Un élément essentiel de l'économie de la pratique consiste à connaître les modes de paiement courants.

OBJECTIF : Analyser les modes de paiement d'une pratique de cinq chirurgiens du centre du Texas, aux États-Unis.

MÉTHODOLOGIE : Les auteurs ont procédé à l'analyse rétrospective des dossiers financiers d'un centre de chirurgie esthétique du Texas. Ils ont colligé les données pour la période de cinq ans s'étalant de 2003 à 2008 et inclus le mode de paiement, l'élément acheté (produit, service ou chirurgie) et le montant versé.

RÉSULTATS : Les auteurs ont analysé plus de 11000 transactions. Le principal mode de paiement des produits et services était la carte de crédit, suivie des chèques, puis des espèces. Dans le cadre des interventions, la forme de paiement la plus courante était le chèque personnel, suivi de la carte de crédit et du financement. Parmi les achats par carte de crédit des produits et des interventions, la grande majorité des patients (plus de $75 \%$ ) utilisaient soit Visa (Visa Inc., États-Unis), soit MasterCard (MasterCard Worldwide, États-Unis). Si la somme de la transaction individuelle dépassait $1000 \$$, le mode de paiement le plus courant passait de la carte de crédit au chèque personnel.

CONCLUSIONS : Dans un effort pour maximiser les revenus, les chirurgiens devraient limiter les paiements par carte de crédit acceptés par la pratique et favoriser le paiement par chèque personnel.
Tn economic terms, cosmetic surgery is considered to be a luxury item and, as such, it follows the ebb and flow of the business cycle (1-3). The 1990s and early 2000s saw a steady trend toward increased demand for cosmetic surgery, products and services up until the recent recession. As the economy fluctuates, so does the plastic surgery market, and many plastic surgeons are now challenged with maintaining the delicate balance of managing a medical practice and running a successful business. Particularly, in these periods of economic difficulty, it is important for surgeons to have a good understanding of financial decision making to best optimize their practice profitability $(2,3)$.

Cosmetic surgery, products and services are an important revenue component for many plastic surgeons. For a business venture to remain profitable, items must be supplied at prices with which the consumer is satisfied $(4,5)$. Interestingly, while the demand has increased, prices have remained relatively flat (6). If raising the cost in proportion to demand is unfavourable, then a strategy of minimizing expenses may be a potential avenue for financial profitability. Many aspects of plastic surgery practice economics have been previously addressed in the literature (7); however, currently, there are no studies regarding the common methods of payment used by patients of a plastic surgery practice. Our goal was to identify the methods of payment used for cosmetic products, services and procedures by reviewing a five-surgeon practice in central Texas, USA. This knowledge may assist plastic surgeons in adjusting the financial management of their practices in an effort to maximize revenue.

\section{PATIENTS AND METHODS}

A retrospective chart review of the financial records of a five-surgeon group practice at a cosmetic surgery centre in Texas, USA, was conducted. Data were collected for the five-year period from 2003 to 2008, and included the method of payment, the item purchased (product, service or surgery) and the dollar amount. Transactions were then separated into groups according to the purchase of a product or procedure to further delineate spending practices. Surgeries performed in the main operating room or outpatient surgery centre were grouped into procedures. All other transactions were included in the products and services group, which included Botox (Allergan Inc, USA), fillers and laser treatments not performed in an operating suite. Credit cards were delineated under the following headings: Visa (Visa Inc, USA), MasterCard (MasterCard Worldwide, Inc), Discover (Discover, USA), American Express (American Express Co, USA) and other. Transactions were also separated according to dollar amounts, and descriptive statistics were used.

\section{RESULTS}

During the five-year period surveyed, more than 11,000 transactions were reviewed, amounting to more than $\$ U S 8,000,000$.

\section{Products and services}

The most commonly used method of payment was credit card (51\%). One-third of purchases were made by personal check and the remainder was paid in cash (Figure 1). Credit card transactions were further

${ }^{1}$ University of Texas Medical Branch, Galveston; ${ }^{2}$ Division of Plastic Surgery, Scott $\mathcal{E}$ White Healthcare, Temple; ${ }^{3}$ Texas AËM University, College Station, Texas, USA

Correspondence: Dr Raman C Mahabir, Division of Plastic Surgery, 2401 South 31st Street, Temple, Texas 76508, USA.

Telephone 254-724-2321,fax 254-724-0315, e-mail rmahabir@swmail.sw.org 


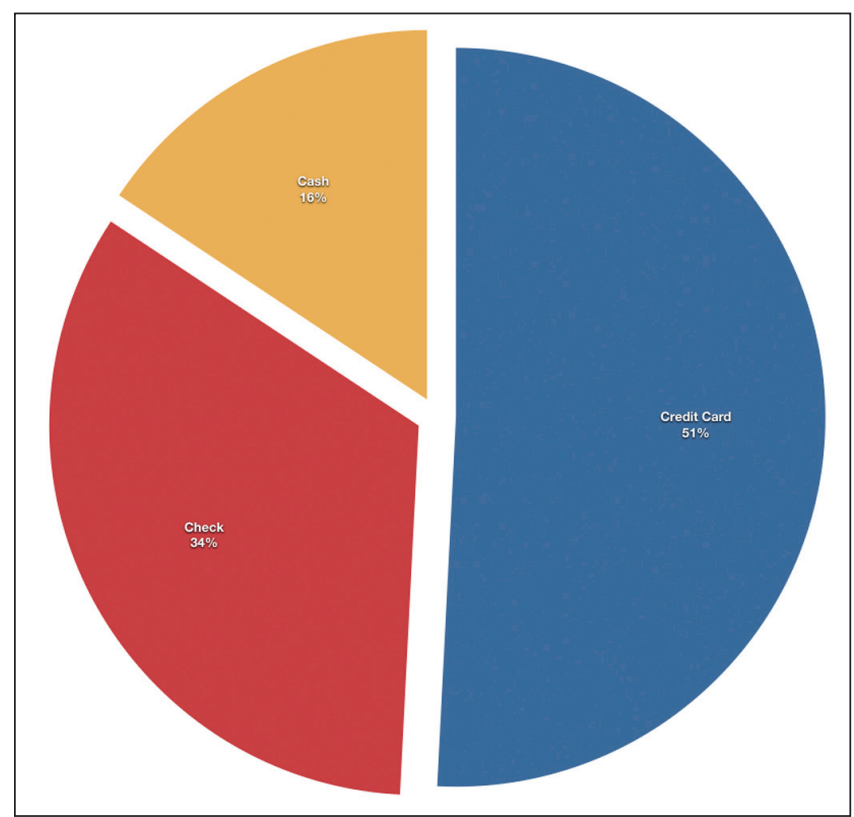

Figure 1) Product and services data - method of payment $(n=10,079)$

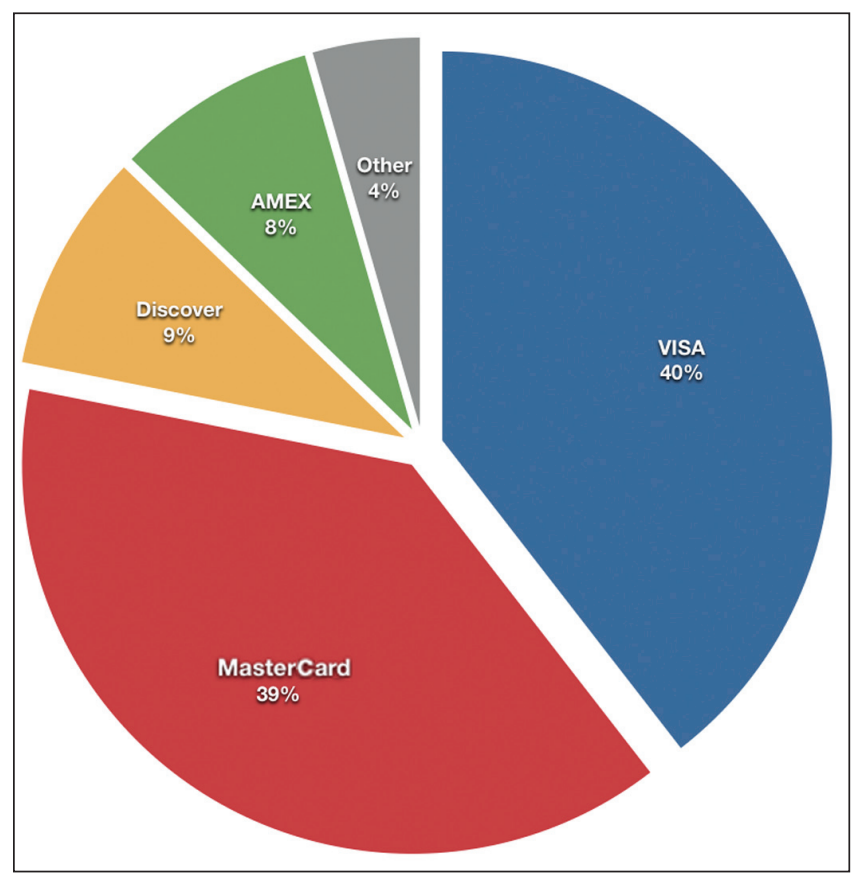

Figure 2) Product and services data - credit card breakdown. American Express (AMEX, American Express Co, USA), Discover (Discover, USA), MasterCard (MasterCard Worldwide, Inc), Visa (Visa Inc, USA)

analyzed to delineate spending trends. Seventy-nine per cent of credit card purchases were made with either Visa or MasterCard (Figure 2). In the case of the Cosmetic Surgery Center (Scott \& White Healthcare, USA), the practice also accepted Discover and American Express ( $9 \%$ and $8 \%$, respectively). Data were analyzed with regard to the dollar amount of each sales transaction, and regardless of the dollar amount, the most common method of payment remained credit card followed by check and cash (Figure 3).

\section{Procedures}

The most common methods of payment were check (37\%) and credit card $(32 \%)$ (Figure 4). Of the credit card purchases, Visa and MasterCard constituted 78\%, and Discover and American Express

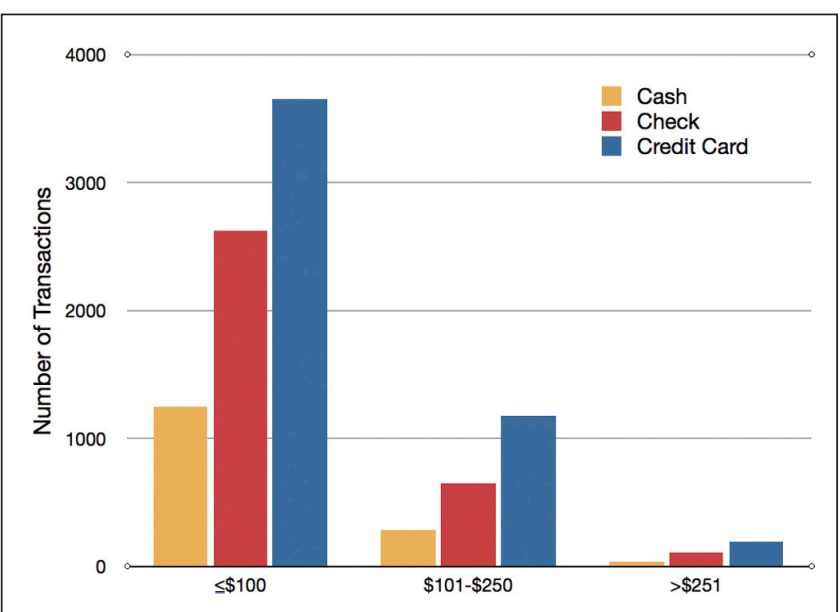

Figure 3) Product and services data - method of payment according to amount paid

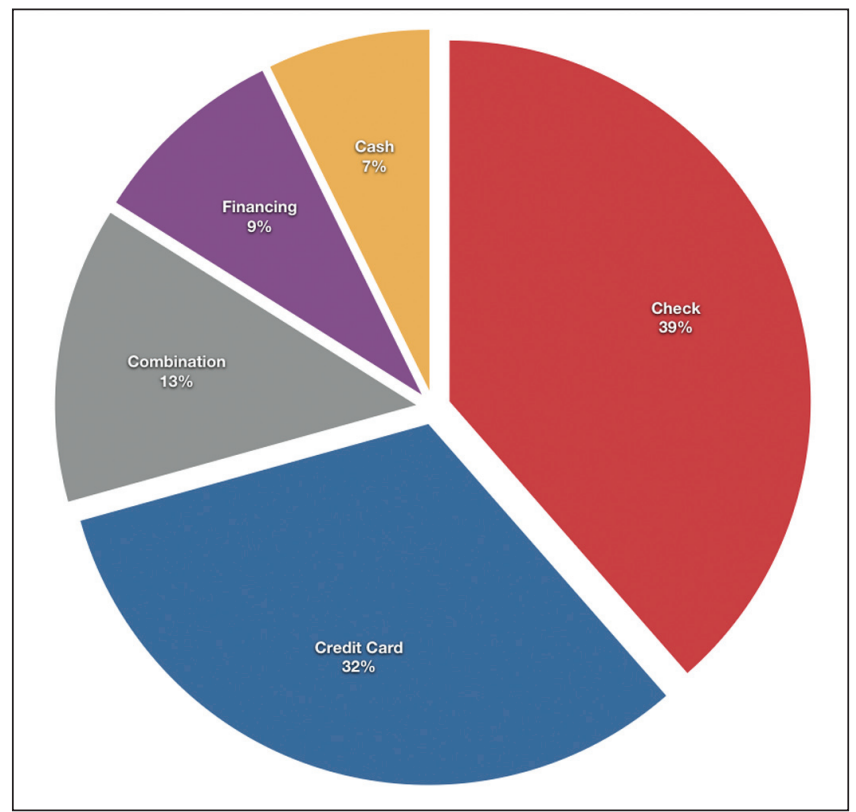

Figure 4) Procedure data - method of payment ( $n=1318)$

were used in 9\% and 7\%, respectively (Figure 5). Procedure data were analyzed according to dollar amount, and results showed that for procedures under $\$ \mathrm{US} 1,000$, the pattern of payment was credit card followed by check and cash. For transactions greater than $\$ \mathrm{US} 1,000$, personal check was the most common method of payment, followed by credit card and cash (Figure 6).

\section{DISCUSSION}

This information will be particularly relevant to plastic surgeons in private practice settings, in which the business model directly affects the bottom line. When a practice decides to accept a credit card as a method of payment, it makes an individualized plan with that specific card company (8). Credit card companies profit in this transaction by charging a 'discount rate', which means that for every purchase made using that card, the credit card company receives a percentage of the total dollar amount of the transaction. The rate typically varies between $1 \%$ and $4 \%$, but can range as high as $12 \%$ with certain types of reward cards. In addition to this discount rate, credit card companies can also add on a variety of additional fees. Examples include setup fees, monthly minimums, cancellation fees, etc. For every different type of credit card a practice chooses to accept, it incurs another combination of these fees. In the case of the Cosmetic Surgery Center, all major credit cards are accepted. 


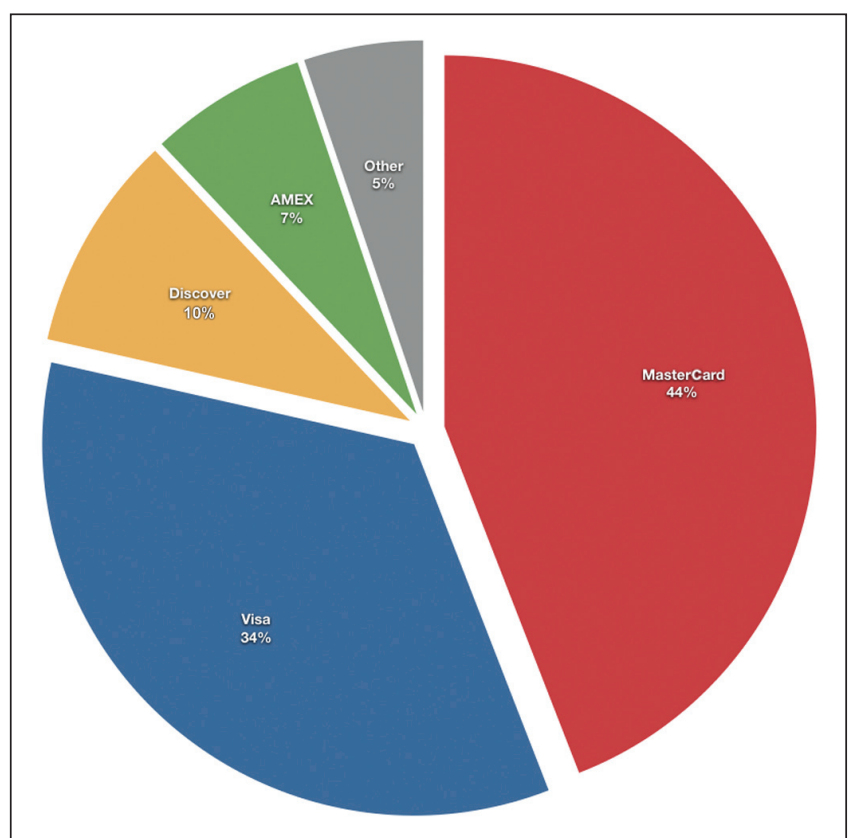

Figure 5) Procedure data - credit card breakdown. American Express (American Express Co, USA), Discover (Discover, USA), MasterCard (MasterCard Worldwide, Inc), Visa (Visa Inc, USA)

Clearly, accepting credit cards does incur a significant cost to the practice. So why accept them at all? Previous economic studies have shown that for luxury items, credit cards increase a consumer's willingness to purchase (9). While that may be the case overall, for cosmetic surgery expenses amounting to more than US $\$ 1,000$, we found that patients preferred personal check to credit card. In comparison with accepting credit cards, a practice receives the full cash value when it accepts a personal check. This transaction may be subject to a nominal processing cost. For example, when the practice deposits a patient's check, the practice's bank (if different from the patient's bank) often must communicate with the patient's bank through a third intermediary bank. This intermediary bank charges a very small processing fee for their participation in the transaction (typically 10 cents per check). These processing rates can be minimized and sometimes eliminated by maintenance of a minimum balance on the part of the practice. If one could encourage the practice of payment by personal check or cash, it stands to reason that the practice could benefit significantly. If our practice had $100 \%$ successfully applied this strategy, we would have saved US $\$ 132,713$ over the five-year period (more than US\$26,500 a year).

It was noteworthy that such a high percentage of credit card purchases were made with either Visa or MasterCard, as opposed to other major credit cards. The authors recognize that this may in fact be a regional- or demographic-linked card preference. Vastly more data from across the country would be required to elucidate this issue. Even without that information, the numbers were substantial enough for our practice to call into question whether it is profitable to continue to accept other credit cards (and their related expenses) that are used far less frequently. Travel reward point Visa cards can charge up to $18 \%$. Most Americans carry several different credit cards. By politely accepting only specific cards, the practice stands to benefit. This of course must be weighed against the possibility of loss of clientele based on this practice. Prospective data collection regarding this issue will help to shed light on this question.

The present study also revealed what the authors considered to be some interesting purchasing habits. For example, patients did not finance any product, service or procedure that cost less than US $\$ 1,000$ at the Cosmetic Surgery Center, and 43 patients brought more than US\$5,000 cash with them as payment.

The limitation of the study is that it was conducted at a single, moderate-sized practice in central Texas. Practice size and geographical

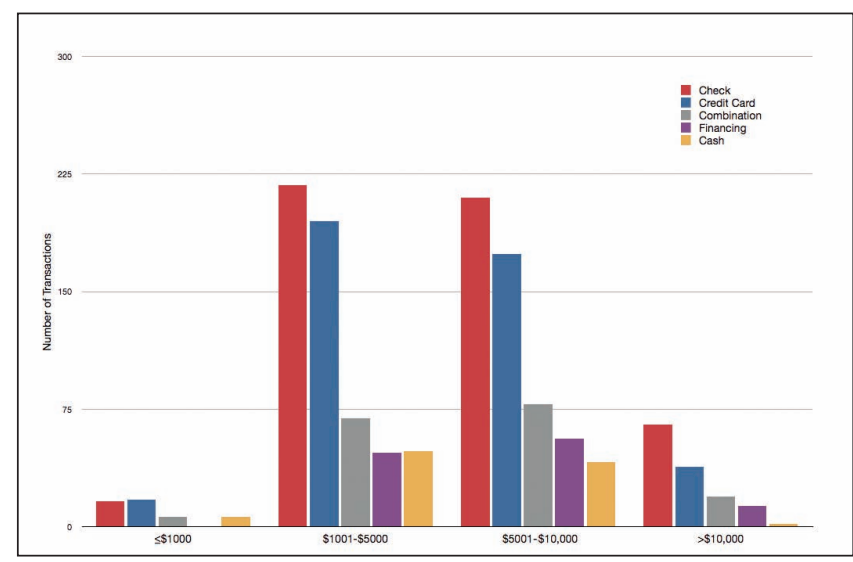

Figure 6) Procedure data - method of payment according to amount paid

location may affect the external validity of these results. It would be interesting to observe whether the pattern holds true in larger cities and in other regions of the country. Additionally, it would be useful to take into account how changes in the macroeconomic climate affect purchasing patterns. 2003 to 2008 were fairly prosperous years nationally, but after a year of recession, it would be interesting to examine whether patients have altered their payment preferences.

\section{CONCLUSION}

The most common method of payment used for cosmetic surgery and products was credit card (an overwhelming majority of which were either Visa or MasterCard). As the amount of the individual transaction increased to over US $\$ 1,000$, the most common method of payment transitioned from credit card to personal check. In an effort to maximize revenue, surgeons should consider limiting the types of credit cards accepted by the practice, and encourage payment through personal check.

CONFLICT OF INTEREST: The authors have no conflicts of interest to declare.

FINANCIAL DISCLOSURE AND PRODUCTS: The authors have no financial interest, consultancies, stock ownership, or other equity interests, patent licensing arrangements or any payments for conducting or publicizing the study described in the article.

\section{REFERENCES}

1. Krieger LM, Shaw WW. The effect of increased plastic surgeon supply on fees for aesthetic surgery: An economic analysis.

Plast Reconstr Surg 1999;104:559-63; discussion 564-5.

2. Krieger LM, Shaw WW. Aesthetic surgery economics: Lessons from corporate boardrooms to plastic surgery practices. Plast Reconstr Surg 2000;105:1205-10; discussion 1211-2.

3. Krieger LM. Cosmetic surgery in times of recession: Macroeconomics for plastic surgeons. Plast Reconstr Surg 2002;110:1347-52.

4. D'Amico RA, Saltz R, Rohrich RJ, et al. Risks and opportunities for plastic surgeons in a widening cosmetic medicine market: Future demand, consumer preferences, and trends in practitioners' services. Plast Reconstr Surg 2008;121:1787-92.

5. Krieger LM, Shaw WW. Pricing strategy for aesthetic surgery: Economic analysis of a resident clinic's change in fees. Plast Reconstr Surg 1999;103:695-700.

6. Krieger LM, Lee GK. The economics of plastic surgery practices: Trends in income, procedure mix, and volume. Plastic and Reconstr Surg 2004;114:192-9.

7. Liu TS, Miller TA. Economic analysis of the future growth of cosmetic surgery procedures. Plast Reconstr Surg 2008;121:404e-412e.

8. Kyle B. The Credit Card Processing Fee. <www.websitemarketingplan. com/payments/Credit-Card-Merchant-Account.html> (Accessed on September 13, 2010).

9. Wright J. Why do merchants accept credit cards? $<$ http://profile.nus.edu.sg/fass/ecsjkdw/RNE_revised_paper.pdf> (Accessed on September 13, 2010). 